\title{
Immigrants' Labour Market Disadvantages Across Western Europe: the Role of Composition and Context
}

\author{
Andreas Damelang $^{1} \cdot$ Sabine Ebensperger $^{1}$ (D) $\cdot$ Felix Stumpf $^{1}$
}

Accepted: 3 March 2021 / Published online: 24 March 2021

(C) The Author(s) 2021

\begin{abstract}
This paper examines why some Western European countries are more successful in integrating immigrants into the labour market than others. Using data from the Programme for the International Assessment of Adult Competencies (PIAAC), we show how the country-specific immigrant composition and context of reception contribute to immigrants' disadvantages across receiving countries. Because the data provide extensive information about relevant characteristics that were often considered unobservable, we can comprehensively model the immigrant composition in receiving countries. We find considerable cross-country differences in immigrants' disadvantages, both in terms of employment and occupational status. Multivariate analyses highlight that a large part of this variation is explained by differences in immigrant compositions, whereas we find little evidence for context effects. Counterfactual simulations corroborate that the extent to which countries succeed with integrating immigrants into the labour market strongly depends on the composition of the immigrants that they receive.
\end{abstract}

Keywords Cross-national research · Immigrants · Labour market · Europe · PIAAC

\section{Introduction}

Europe receives almost one-third of the world's immigrants. In total, the immigrant population in European countries amounts to a remarkable 78 million (United Nations, 2017). Incorporating this large number of immigrants into the labour market is key for successful integration into society and remains a challenge for receiving countries. Several studies unequivocally document that immigrants are at a disadvantage in regard

Sabine Ebensperger

sabine.ebensperger@fau.de

1 Chair of Sociology and Empirical Research Methods, Friedrich-Alexander University

Erlangen-Nürnberg, Findelgasse 7/9, 90402 Nuremberg, Germany 
to their participation in and positioning on the labour market. In relation to natives, immigrants have higher risks of unemployment, and those employed earn lower wages and have lower-quality jobs (cf. Adsera \& Chiswick, 2007; Algan et al., 2010; Ballarino \& Panichella, 2018).

Across Western Europe, international comparisons suggest that these disadvantages of immigrants on the labour market vary across countries. For example, immigrants' chances of being employed and the quality of their jobs are relatively high in the United Kingdom (UK), whereas immigrants in other countries are less prosperous (OECD, 2017; Eurostat, 2018). Thus, immigrants seem to be better integrated into the labour market in some receiving countries than in others.

Understanding why immigrants' disadvantages in the labour market are less severe in some receiving countries than in others is crucial for identifying how ethnic inequality can be effectively reduced. Researchers have put forward two broad strands of explanations for the differences in immigrants' labour market disadvantages across receiving countries (Portes \& Rumbaut, 2001; van Tubergen et al., 2004): (1) the distinct compositions of immigrants in receiving countries, and (2) the distinct contexts of reception that receiving countries provide. Differences in immigrant compositions refer to the fact that immigrants in different receiving countries have different sets of individual characteristics that are relevant for their labour market performance, whereas differences in the context of reception refer to the institutional frameworks and societal conditions in receiving countries that shape immigrants' labour market prospects.

In this study, we shed new light on the question of why immigrants' disadvantages vary across countries. We contribute to this question in two ways. First, we model the composition of immigrants in receiving countries more precisely than before, especially with regard to their endowment with human capital. Second, we analyse the role of the country-specific immigrant composition and the context of reception by simulating counterfactual immigration scenarios. In our analyses, we distinguish between the quantity and quality of labour and reveal gender-specific patterns.

We use internationally harmonized data from the Programme for the International Assessment of Adult Competencies (PIAAC) by the Organization for Economic Cooperation and Development (OECD) to examine immigrants' labour market disadvantages in Western European receiving countries. Because the data provide extensive information about relevant characteristics of immigrants that were often considered "unobservable" in the past (cf. Borjas, 1987, 1994; van Tubergen et al., 2004), we can comprehensively model the immigrant composition in receiving countries with regard to human capital endowments. Beyond information about the respondents' formal qualifications, we consider their numeracy skills as a measure of cognitive ability, and additionally account for their readiness to learn, host language usage, and years since migration. By adding these compositional variables to our empirical models, we can determine whether different levels of immigrant disadvantages in receiving countries go back to different immigrant compositions. From these insights, we can infer to what extent immigrant compositions and contexts of reception affect immigrants' labour market disadvantages across receiving countries.

Moreover, we apply counterfactual immigration scenarios that further illustrate why the disadvantages incurred by immigrants vary across countries. Drawing on the rich compositional data from PIAAC, we first determine immigrants' disadvantages in receiving countries. We then simulate immigrants' disadvantages using counterfactual 
immigrant compositions; that is, we demonstrate the extent to which immigrants in given countries would hypothetically be disadvantaged if these countries had received immigrants with characteristics similar to those of immigrants residing in other countries. These counterfactual simulations make it possible to study, for example, whether immigrants in the UK would still face lower levels of disadvantages if their composition was similar to that of immigrants in Northwestern Europe. In this way, we provide novel insights into how country-specific immigrant compositions and contexts of reception contribute to immigrants' labour market integration.

In our empirical analyses, we consider labour market integration with respect to two relevant outcomes. We study the chances of being employed, and the quality of employment in terms of occupational status according to the International Socio-Economic Index (ISEI) of 2008. This distinction is crucial, because good employment prospects do not necessarily come with good jobs. For example, jobs in the low-skilled sector allow immigrants to find employment relatively easily but represent low status and mobility traps (Wiley, 1967). Moreover, our analyses concern immigrants' outcomes in relation to the native-born population. We argue that in cross-country studies, analysing immigrants' disadvantages rather than their absolute outcomes is appropriate given the differences in baseline employment rates and occupational status across national labour markets. Obviously, it makes a difference whether immigrants succeed with accessing jobs in a country that generally provides for good employment prospects on the one hand, or in a country marked by overall low employment on the other. Furthermore, we examine immigrants' disadvantages separately for each gender, because the positioning of men and women on the labour market follows different patterns (van Tubergen et al., 2004). Finally, our study is comprehensive in that it concerns all first-generation immigrants across nine Western European receiving countries, which are Belgium, Denmark, France, Germany, Italy, the Netherlands, Norway, Spain, and the UK.

The next chapter of this paper lays out the theoretical background of our study, followed by the research hypotheses and empirical strategy. The paper will then go on to introducing the data, variables and methods used in the empirical analyses. Next, the empirical findings will be presented. The paper closes with a discussion of our research and some concluding remarks.

\section{Explaining Immigrants' Disadvantages in the Labour Market}

An essential explanation for immigrants' inferior labour market positioning is that their human capital endowments differ from those of the native population (Chiswick, 1979). To begin with, it is likely that immigrants from less developed countries will have accumulated less human capital than natives. In fact, even immigrants from developed countries may have different skill levels than natives, because some part of human capital is country-specific and cannot be transferred from one country to another (Chiswick \& Miller, 2009; Kanas \& van Tubergen, 2009). Moreover, immigrants' foreign educational certificates may not signal the skills that employers in the receiving country deem relevant (Lancee \& Bol, 2017; Damelang et al., 2019). As a result, immigrants will incur economic disadvantages in the receiving country.

To measure individual human capital endowments, empirical researchers typically rely on standardized educational categories. But because the quality, quantity, content, 
and type of education vary across countries (Smith, 1995), individuals from different countries who formally belong in the same educational category will often have quite different skill sets in reality. Thus, even when immigrants' qualifications are formally similar to qualifications earned in the receiving country, they generate lower returns nonetheless (cf. Zeng \& Xie, 2004; Aleksynska \& Tritah, 2013). ${ }^{1}$ Using data from PIAAC that provide assessments of individuals' actual skills, Prokic-Breuer and McManus (2016) substantiate that within a given educational group, the actual skill sets of immigrants and natives differ considerably.

Considering the discrepancy between formal qualifications and actual ability, we refine our empirical analyses of immigrants' disadvantages by introducing direct measures of cognitive skills. These refined analyses will "provide a more realistic estimate of immigrant-native disparities" (Prokic-Breuer \& McManus, 2016, 412) in labour market outcomes.

In our study, we also rely on data from PIAAC. These data go beyond formal levels of education in that they provide cross-nationally harmonized measures for cognitive skills. Moreover, they include information on individuals' readiness to learn, host language usage, and years since migration. These characteristics must be considered when analysing immigrants' disadvantages because immigrants typically lack country-specific human capital that is relevant for succeeding in the receiving labour market, such as language skills and knowledge about the culture, institutions, and labour market of the receiving country. During their stay in the receiving country, immigrants may improve their human capital by acquiring country-specific skills and knowledge (Chiswick et al., 2005).

\section{Distinct Immigrant Compositions in Receiving Countries}

How immigrants fare in the labour market depends on macro factors that affect the selection of immigrants and their human capital endowments (Borjas, 1987). We focus on three factors that play a decisive role in the composition of immigrants in Western European countries.

First, countries have quite different immigration histories. During the 1950 s to 1970s, several Northwestern European countries recruited low-skilled guest workers from Southern Europe and Turkey to meet their high demand for workers in labourintensive jobs. While these immigrants were originally expected to return to their home countries, many of them stayed permanently. As a result, countries in Northwestern Europe have high numbers of permanent immigrants with relatively low human capital endowments. During the same period, former colonizers such as the UK, Belgium, France, and the Netherlands started receiving substantial numbers of immigrants from their former colonies (although Belgium, France, and the Netherlands were also attracting guest workers around the same time). Due to their colonial hegemony-for example, in terms of the languages, education systems, and skill requirements that they established in their former colonies - their immigrants are more often equipped with skills that are readily applicable (Castagnone et al., 2015). For these immigrants, disadvantages in the receiving labour market will therefore be relatively moderate.

\footnotetext{
${ }^{1}$ Empirically, many studies include information on country of origin to account for different levels of human capital. This is a common approach, but does not adequately reflect the individual's human capital endowment.
} 
Second, countries have different levels of social inequality and welfare systems that differ in their generosity and inclusiveness. Theories of immigrant self-selection predict that these differences will attract immigrant groups of different skill levels. Highly skilled individuals will find it attractive to immigrate to countries with a disperse income distribution that allows them to generate high returns on their skills (Haberfeld et al., 2011). Less skilled individuals, by contrast, will be attracted to countries where earnings are more equally distributed and where more inclusive and generous welfare states offer disadvantaged groups better protection against economic difficulties (Koopmans, 2010).

Third, countries have different demands for low-skilled labour in the secondary sector. In the secondary sector, immigrants can find work relatively easily because it offers less favourable "dead end jobs" that natives tend to avoid (Portes \& Rumbaut, 2006). In fact, for these types of jobs, employers prefer hiring immigrants, attributing positive work ethics to them (MacKenzie \& Forde, 2009). A high demand for lowskilled labour therefore provides a pull-factor that will attract more low-skilled and labour-oriented immigrants.

Following these theoretical considerations, the distinct composition of the immigrants that countries have attracted will determine how immigrants fare in the labour market in relation to natives. Accordingly, we formulate an immigrant composition hypothesis:

H1: Different levels of immigrant disadvantages in receiving countries are explained by differences in immigrant compositions.

Among the receiving countries under investigation, the UK is marked by the most disperse income distribution (OECD, 2015, 20) and the lowest public social expenditures (OECD, 2016a, 109). Moreover, it has strong immigration ties with former colonies that were then part of the British Empire and English is the lingua franca in the world. According to theories of self-selection, immigrants in the UK should therefore be highly skilled and particularly favourably composed overall. The countries in Northwestern Europe, on the other hand, should have attracted more negatively selected immigrant groups due to their more equally distributed income (OECD, 2015, 20), higher public social expenditures (OECD, 2016a, 109), and large guest worker inflows. The Southern European countries Italy and Spain have much more recently become immigration countries, with substantial inflows starting in the 1990s. Both countries have a high demand for low-skilled labour and a large underground economy where illegal economic transactions take place, which should stimulate low-skilled immigration (Castagnone et al., 2015).

A closer look at the most frequent countries of birth of immigrants (OECD, 2017) shows that, according to our theory, many immigrants residing in Belgium, France, the Netherlands, Spain and the UK were born in former colonies and/or in countries with the same mother tongue. Additionally, the categorisation of the most frequent countries of birth of immigrants into developed and other countries (UN, 2020) shows that few immigrants in Italy, Spain, and the Netherlands were born in developed countries, followed by Denmark, the UK, and Germany, while in Belgium, France, and Norway, several frequent countries of birth of immigrants belong to developed countries.

To sum up, due to the differences in immigrant attraction, the immigrant composition should be most favourable in the UK, while immigrants in other countries should be more negatively selected, especially in Southern Europe. As a result, immigrants' 
labour market disadvantages should be lowest in the UK and highest in Southern Europe, whereas Northwestern Europe should rank in between.

\section{Country-Specific Contexts of Reception}

In addition to the immigrant composition, it is argued that immigrants' disadvantages depend on characteristics of the receiving country that lead to different "modes of incorporation" (Portes \& Rumbaut, 2001) and affect immigrants' economic performance (Engelen, 2006). Below, we discuss three societal and labour market features of receiving countries that we expect will have an immediate impact on immigrants' labour market integration.

First, in countries with longer immigration histories, there are denser immigrant networks that support newcomers in finding employment and specific integration policies have been put in place to reduce immigrants' disadvantages in the labour market (Ballarino \& Panichella, 2015). For example, these countries award longer-term work permits and naturalization, or offer guidance and support, such as courses in the host language (cf. Reitz, 2002). Moreover, the native population in old receiving countries has more experience with immigrants. Hence, old immigration countries should provide better opportunities for the labour market incorporation of immigrants than new immigration countries.

Second, institutional approaches suggest that immigrants' disadvantages will depend on the regulation of the receiving labour market. More regulated labour markets are characterized by rules and institutions that restrict market forces and volatility in favour of long-term employment relationships. For example, employment protection legislation may limit fixed-term or temporary employment contracts. In such settings, dissolving employment contracts induces high costs for employers. Consequently, immigrants' chances of getting hired are lower because risk-averse employers avoid hiring foreigntrained candidates whose productivity they cannot reliably assess ( $\mathrm{Li}, 2001)$. Moreover, in regulated labour markets, educational credentials are particularly important for individual career prospects. Because immigrants often lack native credentials, they are less likely to succeed in the labour market (Damelang \& Abraham, 2016). Additionally, regulated labour markets hamper occupational mobility, which limits immigrants' chances to improve their occupational status over time (Zorlu, 2016). As a result, immigrants' chances of getting hired and taking up occupations with high status are said to be lower in regulated labour markets than in flexible ones (Kogan, 2006).

Third, the demand for low-skilled labour in the receiving country also directly affects immigrants' labour market integration. Because the low-skilled sector is typically organized in a rather flexible way, immigrants' chances of accessing employment in this sector are high, even in countries where the labour market is rather rigid overall (Kogan, 2006). However, the low-skilled sector consists of low-paid and unstable jobs with few opportunities for mobility, and therefore bears a high risk of unfavourable segmentation.

Beyond immigrants' individual characteristics, these country-specific contexts of reception may contribute to differences in immigrants' labour market disadvantages across countries. If adjusting for individual characteristics does not fully explain the cross-country differences in immigrants' disadvantages, this indicates that the context of reception directly affects immigrants' labour market disadvantages. On the other hand, if differences in immigrants' individual characteristics fully explain the cross- 
country differences in immigrants' disadvantages, this suggests that no context effects remain once we consider immigrant compositions. Because we argue that both the immigrant composition and the context of reception affect immigrants' labour market integration, some differences in immigrants' disadvantages across countries should persist even when controlling for individual characteristics. Accordingly, we formulate a context of reception hypothesis:

$\mathrm{H} 2$ : Different levels of immigrant disadvantages in receiving countries are explained by the country-specific context of reception, net of immigrant compositions.

Among the receiving countries under consideration, the context of reception in the UK is marked by a long immigration history and highly deregulated labour market, which should foster immigrants' labour market integration. Despite their long immigration history, Northwestern European countries have more regulated labour markets that should be less favourable for immigrants' integration. The new immigrant countries in Southern Europe have a large low-skilled sector and underground economy that supposedly provide immigrants with easily accessible, yet unfavourable jobs (Reyneri \& Fullin, 2011).

Given these differences in the context of reception, immigrants in the UK should have lower disadvantages than immigrants in Northwestern Europe, whereas in Southern Europe, immigrants should have relatively high chances of accessing employment but at the cost of lower occupational status.

\section{Data, Variables, and Method}

For the empirical analyses, we rely on data from the Survey of Adult Skills, which is part of the OECD PIAAC (OECD, 2016b). In addition to extensive background information, the survey includes direct measures of respondents' cognitive skills. These data make it possible to model the country-specific composition of immigrants with respect to their level of education, cognitive abilities, readiness to learn, host language usage, and years since migration. Because all data are harmonized cross-nationally and provide information that is directly comparable across countries, they are ideal for carrying out international comparisons.

We focus on receiving countries in Western Europe, for which we use data from the first round of the survey in $2011 / 2012$. Because we aim to analyse immigrants' disadvantages in terms of employment and occupational status, our analytical samples are restricted to respondents of working age ( 25 to 65 years) in countries where detailed information on respondents' current occupation is available. These countries are Belgium, Denmark, France, Germany, Italy, the Netherlands, Norway, Spain, and the UK.

For the multivariate analyses, we form clusters of countries representing (1) Northwestern Europe (Belgium, Denmark, France, Germany, the Netherlands, and Norway), (2) the UK, and (3) Southern Europe (Italy and Spain). Clustering the countries is necessary to yield sufficient numbers of immigrants for analysis in each group of countries. The formation of clusters follows our theoretical considerations. Countries within clusters have similar immigration histories, labour market characteristics, and social conditions, but there are major differences between clusters. To ensure that clustering does not distort the results, we have also run the multivariate analyses with individual countries. The results are similar and lead to the same conclusions (see Tables 5 and 6 in the Appendix). 
In our analyses, we apply converted full sample weights. This weighting procedure ensures that results are representative of the total population at the country level and that countries within each cluster are weighted equally. Thereby, we avoid that larger countries outweigh smaller countries.

Given our interest in immigrants' labour market disadvantages relative to natives, we compare outcomes of first-generation immigrants to outcomes of the native-born population. ${ }^{2}$ In the remainder of the paper, we will concisely refer to these two groups as "immigrants" and "natives". Table 7 in the Appendix shows the number of observations in the countries and country clusters by immigrant status, for both men and women. ${ }^{3}$

We compare immigrants and natives with respect to two labour market outcomes. First, we study gaps in their chances of being employed. The employment variable takes on a value of one for individuals currently employed or self-employed, and zero for all non-employed individuals, including both unemployed and inactive workers. Measuring employment in these terms is more appropriate than just capturing the risk of being unemployed, because it considers that individuals who do not find employment may also withdraw from the labour market. ${ }^{4}$ Corresponding with the binary measurement, we estimate chances of being employed using logit models. Second, among those employed, we study the immigrant-native divide in occupational status according to the ISEI of 2008. This metric index is well established in international comparative sociological research (Ganzeboom et al., 1992) and ranges from a minimum score of 11 (hunters and trappers, among others) to a maximum score of 89 (judges). We assign status scores by matching the ISEI 2008 to respondents' current occupations according to the International Standard Classification of Occupations (ISCO) 2008, using the freely available conversion tool of Ganzeboom and Treiman (2017). In the multivariate analyses, we estimate ISEI scores using ordinary least squares (OLS) models.

In our models, we effectively control for composition, with variables including level of education, numeracy skills, readiness to learn, host language usage, years since migration, and relevant socio-demographics. ${ }^{5}$ Numeracy skills reflect the essential cognitive ability "to access, use, interpret and communicate mathematical information and ideas" (OECD, 2016b, 48). In the PIAAC survey, each respondent answers a

\footnotetext{
2 The Survey of Adult skills collects data from adults residing in the respective country but not living in institutional collective dwelling units, such as refugee shelters (OECD, 2016c). Thus, PIAAC only covers a fraction of the immigrant population and it is very unlikely, for example, that temporary immigrants such as seasonal workers participate in the survey. Presumably, the immigrants under study will therefore be positively selected and our estimates of immigrant disadvantages in the labour market should prove rather conservative overall; nevertheless, such selection bias is typical of immigrant studies based on population surveys.

${ }^{3}$ Second-generation immigrants are defined as "natives". Unfortunately, case numbers per country cluster are insufficient for running separate analyses for second-generation immigrants. In re-estimations of our main regression models excluding second-generation immigrants from the sample, the interpretations of our findings do not change.

${ }^{4}$ With our operationalisation of non-employment, we cannot differentiate between individuals who cannot find work and those who do not want to work. A thorough distinction between these two groups would be crucial for examining, for example, whether employment differences between immigrants and natives are driven by the supply side or the demand side (Algan et al., 2010). This question, however, is beyond the scope of our paper. Moreover, Ballarino and Panichella (2018) show rather consistent patterns of employment disadvantages for immigrant women across Europe, regardless of different operationalisations of employment—namely, labour market activity, work-related employment, and unconditional employment.

${ }^{5}$ PIAAC does not provide information on migration motives.
} 
subset from the pool of numeracy test items, which yields ten plausible values for every individual in the data (OECD, 2016c). Assessments are reported on a 500-point scale, with higher scores indicating higher levels of numeracy skills. ${ }^{6}$ In addition to cognitive ability, we consider respondents' level of education according to the International Standard Classification of Education (ISCED) 1997. Levels indicate primary education or less (ISCED 1 or less); lower secondary education (ISCED 2, ISCED 3C short); upper secondary and post-secondary, non-tertiary education (ISCED 3A-B, C long, 4A-B-C); tertiary education - professional degrees (ISCED 5B); and tertiary education-bachelor, master, research degree (ISCED 5A, 6).

Other relevant compositional variables include PIAAC's index of readiness to learn, which measures respondents' intrinsic motivation and ambition with six items, such as "I like learning new things" and "I like to get to the bottom of difficult things". With respect to language proficiency, frequent host language usage will improve labour market success (e.g., Chiswick \& Miller, 2007). We consider this by creating a dummy variable that indicates whether the language the respondent mostly speaks at home corresponds with the host language in which the PIAAC survey was carried out. Beyond language usage, we approximate endowments with host country-specific human capital using immigrants' years since migration. As the information on years since migration only occurs for immigrants, this variable takes on a value of zero for natives.

Additional socio-demographic variables in our models include age as well dummy variables for cohabitating with a spouse or partner, and having children. In the models predicting occupational status, we also consider whether respondents usually work fulltime (more than $34 \mathrm{~h}$ per week) or part-time ( $34 \mathrm{~h}$ or less). ${ }^{7}$ Finally, considering that labour market outcomes may differ by sex, we estimate our models separately for men and women. Descriptive statistics of the variables in our models are provided in Table 8 in the Appendix.

We complete our empirical results with a counterfactual analysis, which compares immigrants' factual disadvantages with counterfactual simulations. We illustrate these comparisons using predictive margins. We start by predicting the average employment probabilities and ISEI scores of immigrants and natives in each group of receiving countries using the values of their compositional covariates. Based on these predictions, we calculate their factual disadvantages. Next, we simulate immigrants' outcomes based on counterfactual immigrant compositions. That is, we predict immigrants' labour market outcomes in countries using the values of the compositional covariates of immigrant populations in other countries. Juxtaposing these outcomes with those of natives yields immigrants' counterfactual disadvantages.

\footnotetext{
${ }^{6}$ Besides numeracy skills, the PIAAC data contain measures on literacy skills and problem solving in technology-rich environments. We follow other authors (cf. Forster et al., 2016; Hanushek et al., 2015) and include only numeracy skill scores in our models because the different skill measures correlate very strongly and numeracy skills are considered to be most comparable across countries (Hanushek et al., 2015). Additionally, problem-solving skills are not surveyed in all countries.

${ }^{7}$ The definition of full-time jobs varies between countries as well as within a country. We have used the usual minimum number of hours to be worked as a baseline and set the threshold to $34 \mathrm{~h}$ per week. In France and in some German industries, for example, a full-time job is defined as working $35 \mathrm{~h}$ per week.
} 


\section{Results}

In the presentation of our empirical results, we start by describing the labour market outcomes and composition of immigrants and natives across countries. Next, we present findings from multivariate models and discuss how the immigrant composition and context of reception contribute to immigrants' disadvantages across countries. We then further illustrate our findings by presenting counterfactual immigration scenarios.

\section{Descriptive Findings}

Figure 1 shows employment rates for male and female immigrants and natives in each country, and Fig. 2 displays their mean ISEI scores. In these figures, countries are grouped in the clusters Northwestern Europe, the UK, and Southern Europe.

Immigrants' employment rates fall short of natives' across all Northwestern European countries under consideration. These employment differentials are complemented by severe status differentials between immigrants and natives throughout these countries. In the UK, the divides in both employment and status are considerably smaller, with immigrant men having an even slightly higher employment probability than native men. In Southern Europe, immigrants also fare relatively well in terms of finding employment - in fact, male immigrants in Italy and female immigrants in both Italy and Spain are even more often employed than the native population-but immigrants' occupational status in these countries falls far behind that of natives. To illustrate the considerable cross-country differences in immigrants' status, consider for example that male immigrants in Denmark on average reach the occupational status of "shop supervisors" (ISEI score 44), whereas male immigrants in Italy just slightly exceed that of "shop sales assistants" (ISEI score 28).

Besides the cross-country differences in the labour market outcomes of immigrants, the figures also show considerable differences in the outcomes of natives. This lends support to our argument that to draw valid conclusions on immigrants' integration and positions in the social hierarchy across countries, one must go beyond analysing absolute outcomes and relate immigrants' labour market performance to that of natives.

We expect that differences in immigrant compositions across receiving countries contribute to the international variation in immigrants' labour market disadvantages. Table 1 provides a comparison of the composition of immigrants and natives across the clustered countries separately for each gender. With respect to education and numeracy skills, the immigrant composition appears most favourable in the UK, followed by

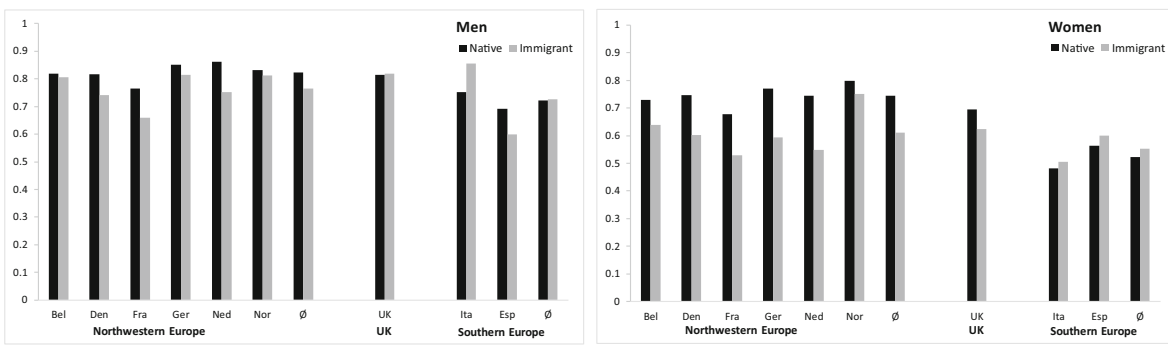

Fig. 1 Employment rates of natives and immigrants across countries 


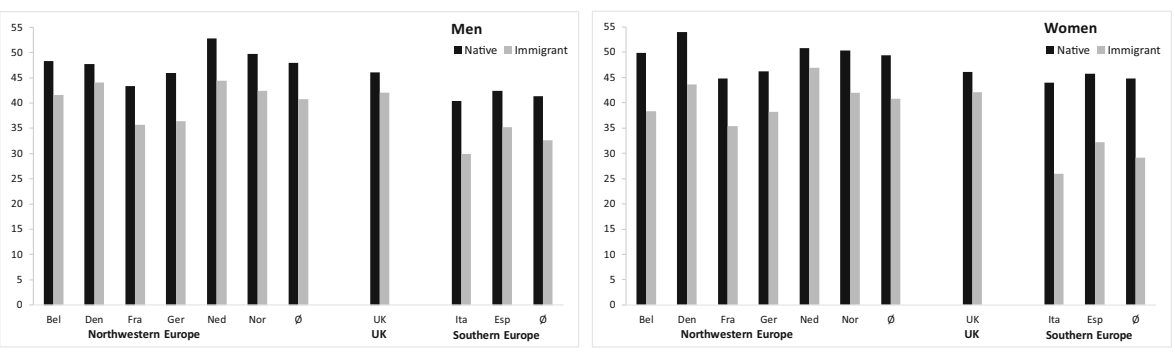

Fig. 2 Mean ISEI scores of natives and immigrants across countries

Northwestern Europe, and Southern Europe. In the UK, immigrants are particularly favourably selected regarding education; they are even more often tertiary educated than the native population. However, despite having formally higher education, immigrants in the UK have considerably lower proficiency in numeracy than natives. This discrepancy highlights that formal qualifications alone would make for a very imprecise indicator of human capital and predictor of immigrants' disadvantages.

Turning to the other compositional variables, immigrants in the UK and Southern Europe are slightly more motivated to learn than immigrants in Northwestern Europe. Moreover, immigrant women in these countries more often speak the host language at home, likely because many of them stem from former colonies. Finally, immigrants' average duration of stay in the receiving country is longest in Northwestern Europe, followed by the UK, and then Southern Europe.

\section{Multivariate Findings}

In this section, we analyse the extent to which different levels of immigrant disadvantages in receiving countries are explained by the country-specific immigrant composition and context of reception. Table 2 shows results from logit regressions that estimate immigrants' employment disadvantages, and Table 3 shows results from OLS regressions that estimate status disadvantages.

To identify cross-country differences, all regression models include interaction terms of the immigrant status with the country clusters. We use the Northwestern European cluster as reference because our descriptive findings show severe employment and status disadvantages for immigrants in these countries. In this way, we can test if immigrants in the UK are better off and if disadvantages of immigrants in Southern Europe are twofold with lower employment, but even higher status disadvantages.

Model 1 in Table 2 shows estimates for immigrant men's disadvantages in employment across the countries. The negative Immigrant coefficient indicates that in Northwestern Europe, the chance of being employed is lower among immigrant men than among native men. The interaction terms Immigrant $\times U K$ and Immigrant $\times$ Southern Europe reflect the extent to which the disadvantages of immigrants in the UK and immigrants in Southern Europe differ from the disadvantages of immigrants in Northwestern Europe. Both coefficients of interactions are positive, whereas the coefficient for Southern Europe only barely is statistically significant. These positive interactions mean that immigrants are less disadvantaged in finding employment in the UK and Southern Europe than in Northwestern Europe. The negative and significant Country 
Table 1 Composition of natives and immigrants across countries

\begin{tabular}{|c|c|c|c|c|c|c|}
\hline \multirow[t]{2}{*}{ Variable } & \multicolumn{2}{|c|}{ Northwestern Europe } & \multicolumn{2}{|l|}{ UK } & \multicolumn{2}{|c|}{ Southern Europe } \\
\hline & Men & Women & Men & Women & Men & Women \\
\hline \multicolumn{7}{|c|}{ Tertiary education $(\%)$} \\
\hline Natives & 35.3 & 38.6 & 37.2 & 37.8 & 22.0 & 25.3 \\
\hline Immigrants & 34.5 & 35.3 & 50.3 & 58.7 & 13.4 & 17.3 \\
\hline \multicolumn{7}{|c|}{ Numeracy skills (mean) } \\
\hline Natives & 287.0 & 271.8 & 275.5 & 260.8 & 254.7 & 241.3 \\
\hline Immigrants & 243.4 & 228.2 & 242.7 & 229.9 & 232.6 & 224.2 \\
\hline \multicolumn{7}{|c|}{ Readiness to learn (mean) } \\
\hline Natives & 2.0 & 1.9 & 2.1 & 2.0 & 2.2 & 2.1 \\
\hline Immigrants & 2.0 & 1.9 & 2.2 & 2.1 & 2.2 & 2.1 \\
\hline \multicolumn{7}{|c|}{ Host language usage (\%) } \\
\hline Immigrants & 51.1 & 55.1 & 55.4 & 64.1 & 50.1 & 66.1 \\
\hline \multicolumn{7}{|c|}{ Years since migration (mean) } \\
\hline Immigrants & 20.3 & 18.5 & 17.1 & 15.6 & 13.3 & 10.9 \\
\hline
\end{tabular}

Numeracy skills are reported on a 500-point scale; the index of readiness to learn ranges between -1.07 and 4.64 in our sample

cluster effect for Southern Europe illustrates that native males in Southern Europe have lower chances of being employed than native males in Northwestern Europe.

Model 2 differs from model 1 in that it includes additional variables to thoroughly control for composition. More specifically, model 2 predicts men's chances of being employed net of their human capital variables and socio-demographic characteristics. In contrast to the coefficients obtained from model 1, the interaction effects Immigrant $\times U K$ and Immigrant $\times$ Southern Europe are no longer statistically significant when controlling for composition. Thus, different levels of immigrant disadvantages in receiving countries are explained by differences in immigrant compositions. Despite adjusting for compositional variables, the Immigrant coefficient is still statistically significant and considerably high. Because we control for years since migration, the coefficient pertains to immigrants, which have immigrated not even one year ago. These recent immigrants have limited host country-specific human capital and, consequently, they incur high labour market disadvantages.

Accordingly, models 3 and 4 show the estimations for women, which yield results similar to those for men. Employment disadvantages of immigrant women are significantly lower in the UK and in Southern Europe than in Northwestern Europe (model 3 ). Net of composition (model 4), differences between Northwestern Europe and the UK diminish. However, in contrast to the results obtained for men, employment disadvantages of immigrant women are persistently lower in Southern Europe than in Northwestern Europe.

Because interaction effects in logit models must be interpreted with caution (e.g., Mood, 2010), we applied two alternative estimation strategies to ensure that the 
Table 2 Logistic regression models on employment, logit coefficients from gender-specific models

\begin{tabular}{|c|c|c|c|c|}
\hline \multirow[t]{2}{*}{ DV: employed } & \multicolumn{2}{|l|}{ Men } & \multicolumn{2}{|l|}{ Women } \\
\hline & Model 1 & Model 2 & Model 3 & Model 4 \\
\hline Immigrant (effect for Northwestern Europe) & $\begin{array}{l}-0.385 * * * \\
(0.070)\end{array}$ & $\begin{array}{l}-0.580 * * * \\
(0.163)\end{array}$ & $\begin{array}{l}-0.620 * * * \\
(0.060)\end{array}$ & $\begin{array}{l}-0.741 \text { **** } \\
(0.127)\end{array}$ \\
\hline \multicolumn{5}{|l|}{ Interaction effects } \\
\hline Immigrant $\times \mathrm{UK}$ & $\begin{array}{l}0.419 * \\
(0.204)\end{array}$ & $\begin{array}{l}0.192 \\
(0.231)\end{array}$ & $\begin{array}{l}0.303 * \\
(0.149)\end{array}$ & $\begin{array}{l}-0.102 \\
(0.169)\end{array}$ \\
\hline Immigrant $\times$ Southern Europe & $\begin{array}{l}0.261+ \\
(0.152)\end{array}$ & $\begin{array}{l}-0.051 \\
(0.180)\end{array}$ & $\begin{array}{l}0.791 * * * \\
(0.127)\end{array}$ & $\begin{array}{l}0.606 * * * \\
(0.153)\end{array}$ \\
\hline \multicolumn{5}{|l|}{ Country cluster (effect for natives) } \\
\hline UK & $\begin{array}{l}-0.071 \\
(0.069)\end{array}$ & $\begin{array}{l}0.043 \\
(0.078)\end{array}$ & $\begin{array}{l}-0.239 * * * \\
(0.055)\end{array}$ & $\begin{array}{l}-0.161 * * \\
(0.062)\end{array}$ \\
\hline Southern Europe & $\begin{array}{l}-0.589 * * * \\
(0.049)\end{array}$ & $\begin{array}{l}-0.341 * * * \\
(0.059)\end{array}$ & $\begin{array}{l}-0.981 * * * \\
(0.043)\end{array}$ & $\begin{array}{l}-0.727 * * * \\
(0.050)\end{array}$ \\
\hline Level of education: primary or less & & Ref. & & Ref. \\
\hline Lower secondary & & $\begin{array}{l}0.423 * * * \\
(0.081)\end{array}$ & & $\begin{array}{l}0.488 * * * \\
(0.073)\end{array}$ \\
\hline Upper secondary and post-secondary, non-tertiary & & $\begin{array}{l}0.577 * * * \\
(0.079)\end{array}$ & & $\begin{array}{l}0.953 * * * \\
(0.072)\end{array}$ \\
\hline Tertiary_-professional degree & & $\begin{array}{l}0.838 * * * \\
(0.104)\end{array}$ & & $\begin{array}{l}1.405 * * * \\
(0.088)\end{array}$ \\
\hline Tertiary-bachelor's, master's, research degree & & $\begin{array}{l}1.022 * * * \\
(0.096)\end{array}$ & & $\begin{array}{l}1.490 * * * \\
(0.084)\end{array}$ \\
\hline Numeracy skills & & $\begin{array}{l}0.006 * * * \\
(0.0005)\end{array}$ & & $\begin{array}{l}0.005 * * * \\
(0.0005)\end{array}$ \\
\hline Readiness to learn & & $\begin{array}{l}0.055 * \\
(0.024)\end{array}$ & & $\begin{array}{l}0.091 * * * \\
(0.021)\end{array}$ \\
\hline Host language usage & & $\begin{array}{l}-0.123 \\
(0.109)\end{array}$ & & $\begin{array}{l}0.258 * * \\
(0.090)\end{array}$ \\
\hline Years since migration & & $\begin{array}{l}0.011 * \\
(0.005)\end{array}$ & & $\begin{array}{l}0.018 * * * \\
(0.004)\end{array}$ \\
\hline Age & & $\begin{array}{l}-0.069 * * * \\
(0.003)\end{array}$ & & $\begin{array}{l}-0.037 * * * \\
(0.002)\end{array}$ \\
\hline Living with a spouse or partner & & $\begin{array}{l}0.732 * * * \\
(0.051)\end{array}$ & & $\begin{array}{l}0.111 * * \\
(0.043)\end{array}$ \\
\hline Having children & & $\begin{array}{l}0.482 * * * \\
(0.056)\end{array}$ & & $\begin{array}{l}-0.022 \\
(0.050)\end{array}$ \\
\hline Constant & $\begin{array}{l}1.543 * * * \\
(0.026)\end{array}$ & $\begin{array}{l}1.632 * * * \\
(0.218)\end{array}$ & $\begin{array}{l}1.066 \text { *** } \\
(0.022)\end{array}$ & $\begin{array}{l}0.141 \\
(0.183)\end{array}$ \\
\hline Observations & 20,943 & 20,943 & 22,937 & 22,937 \\
\hline
\end{tabular}

Robust standard errors in parentheses; $+p<0.10, * p<0.05, * * p<0.01$, *** $p<0.001$

presented results are robust. We re-estimated country differences in immigrant disadvantages using average marginal effects and linear probability models. Both strategies yielded comparable results. A table with the average marginal effects can be found in the Appendix (Table 9). 
Table 3 Linear regression models on the occupational status, regression coefficients from gender-specific models

\begin{tabular}{|c|c|c|c|c|}
\hline \multirow[t]{2}{*}{ DV: occupational status (ISEI) } & \multicolumn{2}{|l|}{ Men } & \multicolumn{2}{|l|}{ Women } \\
\hline & Model 1 & Model 2 & Model 3 & Model 4 \\
\hline Immigrant (effect for Northwestern Europe) & $\begin{array}{l}-7.547 * * * \\
(0.729)\end{array}$ & $\begin{array}{l}-6.283 * * * \\
(1.128)\end{array}$ & $\begin{array}{l}-8.534 * * * \\
(0.810)\end{array}$ & $\begin{array}{l}-7.964 * * * \\
(1.160)\end{array}$ \\
\hline \multicolumn{5}{|l|}{ Interaction effects } \\
\hline Immigrant $\times$ UK & $\begin{array}{l}3.473 \\
(2.116)\end{array}$ & $\begin{array}{l}-0.831 \\
(1.699)\end{array}$ & $\begin{array}{l}4.514 * \\
(1.893)\end{array}$ & $\begin{array}{l}-1.852 \\
(1.537)\end{array}$ \\
\hline Immigrant $\times$ Southern Europe & $\begin{array}{l}-0.925 \\
(1.568)\end{array}$ & $\begin{array}{l}0.409 \\
(1.339)\end{array}$ & $\begin{array}{l}-6.516 * * * \\
(1.599)\end{array}$ & $\begin{array}{l}-2.996 * \\
(1.329)\end{array}$ \\
\hline \multicolumn{5}{|l|}{ Country cluster (effect for natives) } \\
\hline $\mathrm{UK}$ & $\begin{array}{l}-1.887 \text { ** } \\
(0.680)\end{array}$ & $\begin{array}{l}-1.134 * \\
(0.545)\end{array}$ & $\begin{array}{l}-3.223 * * * \\
(0.618)\end{array}$ & $\begin{array}{l}-1.812 \text { *** } \\
(0.517)\end{array}$ \\
\hline Southern Europe & $\begin{array}{l}-6.653 * * * \\
(0.484)\end{array}$ & $\begin{array}{l}-0.979 * \\
(0.398)\end{array}$ & $\begin{array}{l}-4.525 * * * \\
(0.559)\end{array}$ & $\begin{array}{l}-0.855 * \\
(0.423)\end{array}$ \\
\hline Level of education: primary or less & & Ref. & & Ref. \\
\hline Lower secondary & & $\begin{array}{l}1.724 * * \\
(0.630)\end{array}$ & & $\begin{array}{l}3.296 * * * \\
(0.680)\end{array}$ \\
\hline Upper secondary and post-secondary, non-tertiary & & $\begin{array}{l}5.691 * * * \\
(0.624)\end{array}$ & & $\begin{array}{l}9.725 * * * \\
(0.668)\end{array}$ \\
\hline Tertiary—professional degree & & $\begin{array}{l}16.313 * * * \\
(0.794)\end{array}$ & & $\begin{array}{l}22.868 * * * \\
(0.778)\end{array}$ \\
\hline Tertiary_bachelor's, master's, research degree & & $\begin{array}{l}28.702 * * * \\
(0.721)\end{array}$ & & $\begin{array}{l}31.480 * * * \\
(0.747)\end{array}$ \\
\hline Numeracy skills & & $\begin{array}{l}0.085 * * * \\
(0.004)\end{array}$ & & $\begin{array}{l}0.079 * * * \\
(0.004)\end{array}$ \\
\hline Readiness to learn & & $\begin{array}{l}2.117 * * * \\
(0.166)\end{array}$ & & $\begin{array}{l}1.842 * * * \\
(0.174)\end{array}$ \\
\hline Host language usage & & $\begin{array}{l}0.837 \\
(0.710)\end{array}$ & & $\begin{array}{l}1.340+ \\
(0.793)\end{array}$ \\
\hline Years since migration & & $\begin{array}{l}0.171 * * * \\
(0.040)\end{array}$ & & $\begin{array}{l}0.219 * * * \\
(0.043)\end{array}$ \\
\hline Age & & $\begin{array}{l}0.144 * * * \\
(0.015)\end{array}$ & & $\begin{array}{l}0.143 * * * \\
(0.015)\end{array}$ \\
\hline Living with a spouse or partner & & $\begin{array}{l}1.529 * * * \\
(0.381)\end{array}$ & & $\begin{array}{l}0.625+ \\
(0.348)\end{array}$ \\
\hline Having children & & $\begin{array}{l}-0.598 \\
(0.383)\end{array}$ & & $\begin{array}{l}-1.058 * * \\
(0.377)\end{array}$ \\
\hline Full-time work & & $\begin{array}{l}0.405 \\
(0.487)\end{array}$ & & $\begin{array}{l}2.714 * * * \\
(0.306)\end{array}$ \\
\hline Constant & $\begin{array}{l}48.020 * * * \\
(0.227)\end{array}$ & $\begin{array}{l}-1.998 \\
(1.526)\end{array}$ & $\begin{array}{l}49.360 * * * \\
(0.232)\end{array}$ & $\begin{array}{l}-2.130 \\
(1.524)\end{array}$ \\
\hline Observations & 16,477 & 16,477 & 15,729 & 15,729 \\
\hline Adjusted $R^{2}$ & 0.026 & 0.432 & 0.031 & 0.448 \\
\hline
\end{tabular}

Robust standard errors in parentheses, $+p<0.10, * p<0.05, * * p<0.01$, *** $p<0.001$ 
Moving on to Table 3, we discuss differences in immigrants' disadvantages in terms of ISEI scores. The coefficients obtained from model 1 show that immigrant men in Northwestern Europe face severe gross disadvantages in occupational status compared with natives. On average, their ISEI score is 7.547 points lower. Albeit statistically insignificant, the positive interaction term Immigrant $\times U K$ points to lower status disadvantages in the UK. The small and insignificant interaction term Immigrant $x$ Southern Europe illustrates that status disadvantages are similar in Southern Europe and in Northwestern Europe. Again, differences between the UK and Northwestern Europe diminish when additionally controlling for compositional covariates in model 2.

Cross-country differences in status disadvantages appear more pronounced among immigrant women. According to model 3, their disadvantages amount to 8.534 points in Northwestern Europe, whereas they are only about half the size in the UK and substantially higher in Southern Europe. Immigrant women's lower status disadvantages in the UK are fully explained by their composition. This does not pertain to Southern Europe (model 4). Net of composition, differences remain, with immigrant women in Southern Europe facing higher status disadvantages than in Northwestern Europe.

\section{Counterfactual Analysis}

In the counterfactual analysis, we expand on the insights from the multivariate regressions and shed further light on the role of immigrant compositions and contexts of reception for explaining cross-country differences in immigrants' labour market disadvantages. To this end, we compare immigrants' real disadvantages with counterfactual simulations. Results are shown in Table 4. The top panel contains the predictions for natives and immigrants in Northwestern Europe, the middle panel for the UK, and the bottom panel for Southern Europe.

Except for men's employment probabilities, our results show a clear pattern: in any group of receiving countries, the disadvantages of immigrants would be lowest if they were composed like the immigrants in the UK, and highest if they were composed like these in Southern Europe. Taking the Northwestern European receiving countries as an example, the employment probability is 0.74 for native women and 0.61 for immigrant women, which yields an actual difference of -0.13 points. This difference is highly statistically significant. Turning to the counterfactual predictions, if Northwestern Europe had received immigrant women composed like immigrant women in the UK, the difference would be substantially lower $(-0.06)$, albeit still statistically significant, and if it had received immigrant women composed like those in Southern Europe, the difference would be somewhat larger $(-0.15)$. Regarding occupational status, actual ISEI differentials in Northwestern Europe are about -8 points for men and women. According to the counterfactual simulations, these differentials would be around -4 if the composition of immigrants was similar to that in the UK, and about - 15 if it was similar to that in Southern Europe. Noteworthy, if Southern Europe had received those immigrant men that actually reside in the UK, these immigrants would even have outperformed the Southern European native males with their occupational status $(+2)$.

In contrast to these findings, the employment differentials between native and immigrant men hardly change when applying counterfactual immigrant compositions, suggesting that there is not much variation in the labour market attachment of immigrant men with different characteristics. 


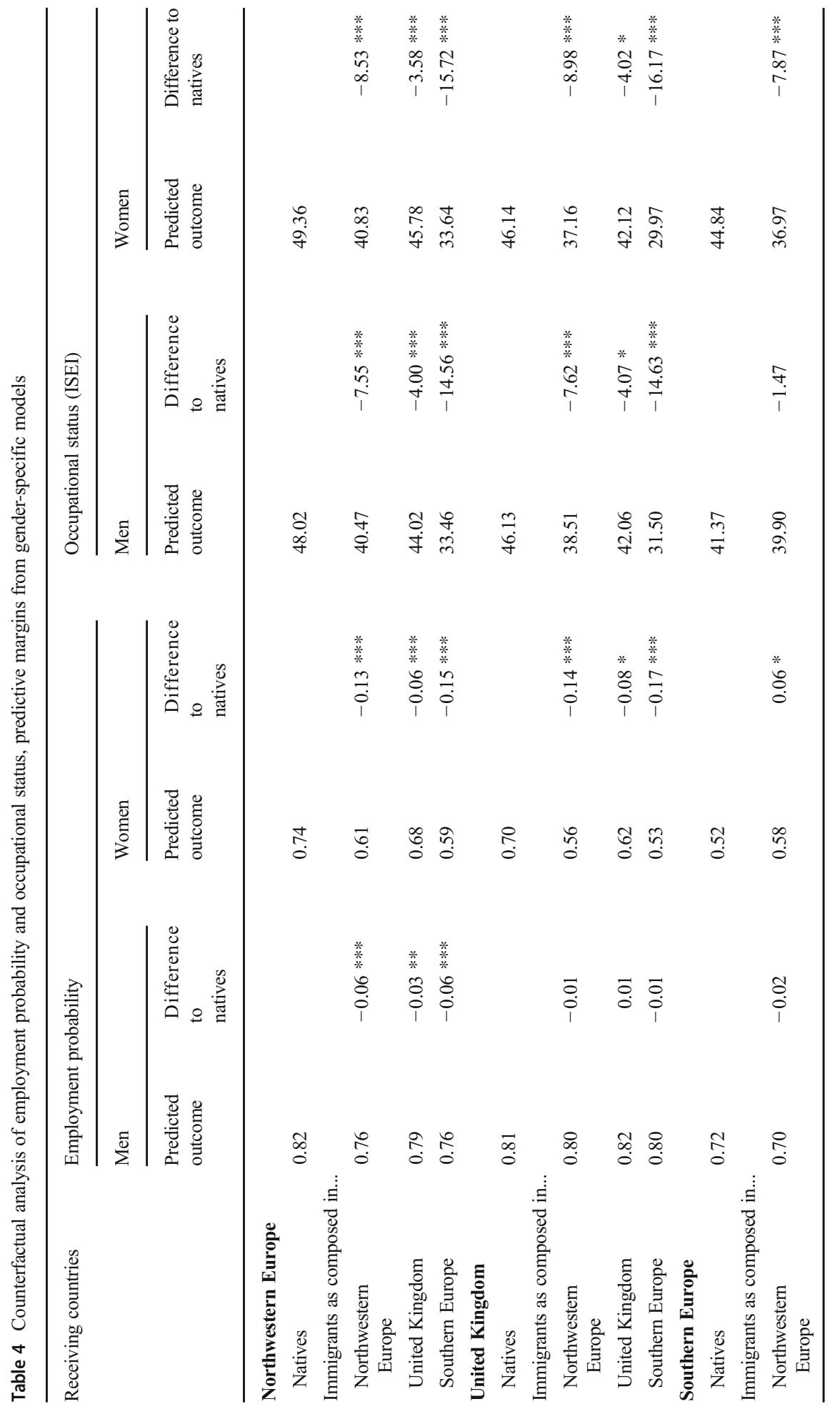




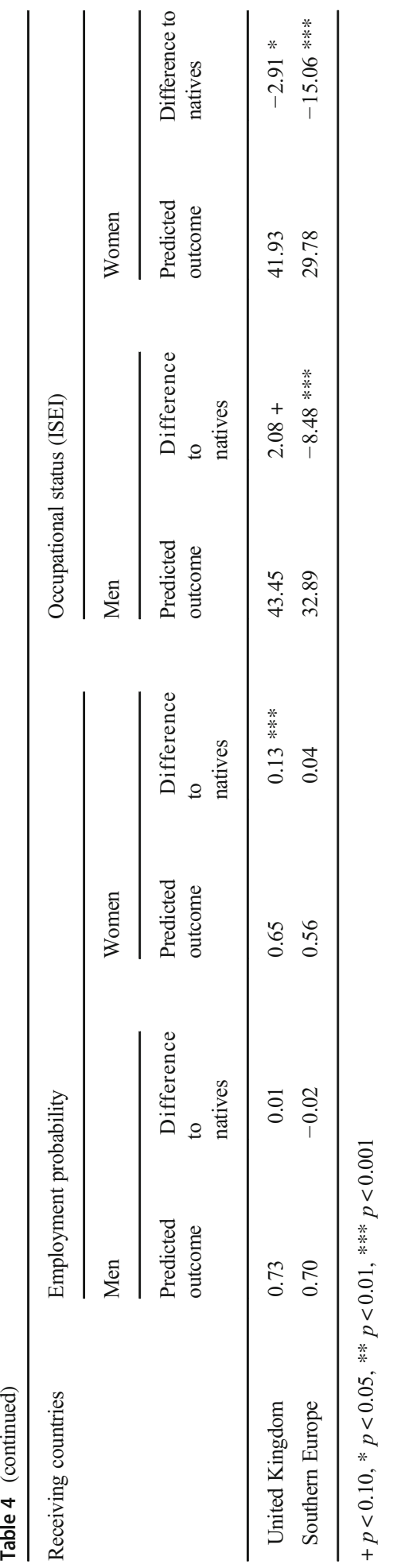




\section{Discussion and Conclusion}

The aim of this study is to scrutinize why the incorporation of immigrants into the labour market is more successful in some Western European countries than in others. Theoretically, cross-country differences in immigrants' labour market disadvantages may, on the one hand, result from the distinct compositions of immigrants in receiving countries and, on the other hand, from the distinct contexts of reception that receiving countries provide. Using internationally harmonized data from the first round of PIAAC for nine Western European receiving countries (Belgium, Denmark, France, Germany, Italy, the Netherlands, Norway, Spain, and the UK), we examine how the country-specific immigrant composition and context of reception contribute to immigrants' disadvantages in the labour market regarding employment chances and the occupational status. A key advantage of our data is that they allow us to model immigrant compositions thoroughly, as we consider formal qualifications, numeracy skills, readiness to learn, host language usage, years since migration, and sociodemographics.

Our results show that the composition of the immigrant population widely differs between receiving countries. Immigrants in the UK show the most favourable human capital endowments, followed by immigrants in Northwestern Europe, and Southern Europe. These distinct immigrant compositions explain a large part of the variation in immigrants' disadvantages across countries. In fact, after controlling for our rich compositional information, immigrants in the UK are not better off on the labour market than immigrants in Northwestern Europe. This finding is in line with previous studies that explicitly model the flexibility of receiving labour markets and do not find that immigrants fare better in flexible labour markets per se (Fleischmann \& Dronkers, 2010; Pichler, 2011; Lancee, 2016).

Nevertheless, there is some evidence that the context of reception affects immigrants' labour market integration, as composition alone cannot fully explain differences in females' labour market disadvantages. Female immigrants in Southern Europe show lower employment disadvantages, but higher status disadvantages at the same time. This twofold pattern is in line with theory, as the huge low-skilled sector and underground economy in Southern Europe offer good employment chances in low-skilled jobs with poor career prospects, for example, in domestic and personal care services (di Belgiojoso \& Ortensi, 2019). In line with our results, Ballarino and Panichella (2018) find this "trade-off between unemployment and job quality" for immigrant women in Southern Europe. They assume that in these countries, especially women of lowincome families have to work on the labour market in order to bear the migrationinduced costs. Consequently, they are pushed to the low segments of the labour market (Ballarino \& Panichella, 2018).

We further illustrate how immigrant compositions and contexts of reception contribute to variation in disadvantages across countries by applying counterfactual immigration scenarios. The results of these simulations corroborate that the composition of immigrants is key for explaining their labour market disadvantages across countries. Due to their most favourable human capital endowments, immigrants that actually reside in the UK would hypothetically incur the lowest disadvantages in any receiving context. The less favourably composed immigrants in Southern Europe would generally incur the most severe disadvantages. 
Although we find only some evidence for direct context effects across the nine Western European receiving countries, the context of reception is still important for the labour market integration of immigrants. One must remember that differences in immigrant compositions also result from individuals self-selecting into or out of specific contexts. According to our theory, the UK's disperse income distribution and low public social expenditures as well as strong immigration ties with former colonies have led to highly skilled immigration inflows. That is, the immigrant population in the UK is not most favourably composed by chance, but because the UK has attracted this group of immigrants in the first place. Institutional frameworks and societal conditions in the receiving country, thus, more indirectly contribute to immigrants' labour market integration (cf. Reitz, 2002; Pichler, 2011). Consequently, the context of reception affects cross-country differences in immigrants' disadvantages through indirect channels. This selectivity calls for further research on the motives and resources of the individuals who choose to immigrate (cf. Ichou, 2014; Diehl et al., 2016; Polavieja et al., 2018). Likewise, future research should consider potential selectivity in return migration, which will hinge on individuals' success with integrating into the host labour market.

\section{Appendix}

Table 5 Logistic regression models on employment, logit coefficients from gender-specific models with single countries

\begin{tabular}{|c|c|c|c|c|}
\hline \multirow[t]{2}{*}{ DV: employed } & \multicolumn{2}{|l|}{ Men } & \multicolumn{2}{|l|}{ Women } \\
\hline & Model 1 & Model 2 & Model 3 & Model 4 \\
\hline Immigrant (effect for France) & $\begin{array}{l}-0.522 * * * \\
(0.131)\end{array}$ & $\begin{array}{l}-0.569 * \\
(0.234)\end{array}$ & $\begin{array}{l}-0.626 * * * \\
(0.122)\end{array}$ & $\begin{array}{l}-0.671 * * * \\
(0.185)\end{array}$ \\
\hline \multicolumn{5}{|l|}{ Interaction effects } \\
\hline Immigrant $\times$ Belgium \& Netherlands & $\begin{array}{l}0.082 \\
(0.200)\end{array}$ & $\begin{array}{l}-0.027 \\
(0.231)\end{array}$ & $\begin{array}{l}-0.078 \\
(0.170)\end{array}$ & $\begin{array}{l}-0.238 \\
(0.195)\end{array}$ \\
\hline Immigrant $\times$ Germany & $\begin{array}{l}0.264 \\
(0.228)\end{array}$ & $\begin{array}{l}0.190 \\
(0.262)\end{array}$ & $\begin{array}{l}-0.199 \\
(0.193)\end{array}$ & $\begin{array}{l}-0.364+ \\
(0.220)\end{array}$ \\
\hline Immigrant $\times$ Denmark & $\begin{array}{l}0.078 \\
(0.180)\end{array}$ & $\begin{array}{l}-0.361+ \\
(0.217)\end{array}$ & $\begin{array}{l}-0.043 \\
(0.158)\end{array}$ & $\begin{array}{l}-0.201 \\
(0.184)\end{array}$ \\
\hline Immigrant $\times$ Norway & $\begin{array}{l}0.381+ \\
(0.231)\end{array}$ & $\begin{array}{l}0.063 \\
(0.273)\end{array}$ & $\begin{array}{l}0.360+ \\
(0.211)\end{array}$ & $\begin{array}{l}0.292 \\
(0.242)\end{array}$ \\
\hline Immigrant $\times$ UK & $\begin{array}{l}0.556 * \\
(0.232)\end{array}$ & $\begin{array}{l}0.169 \\
(0.272)\end{array}$ & $\begin{array}{l}0.308+ \\
(0.183)\end{array}$ & $\begin{array}{l}-0.209 \\
(0.213)\end{array}$ \\
\hline Immigrant $\times$ Italy \& Spain & $\begin{array}{l}0.398 * \\
(0.188)\end{array}$ & $\begin{array}{l}-0.070 \\
(0.238)\end{array}$ & $\begin{array}{l}0.796 \text { *** } \\
(0.166)\end{array}$ & $\begin{array}{l}0.510 * \\
(0.202)\end{array}$ \\
\hline \multicolumn{5}{|l|}{ Country (effect for natives) } \\
\hline Belgium \& Netherlands & $\begin{array}{l}0.471 * * * \\
(0.067)\end{array}$ & $\begin{array}{l}0.332 * * * \\
(0.074)\end{array}$ & $\begin{array}{l}0.282 \text { *** } \\
(0.058)\end{array}$ & $\begin{array}{l}0.241 * * * \\
(0.064)\end{array}$ \\
\hline
\end{tabular}


Table 5 (continued)

\begin{tabular}{|c|c|c|c|c|}
\hline \multirow[t]{2}{*}{ DV: employed } & \multicolumn{2}{|l|}{ Men } & \multicolumn{2}{|l|}{ Women } \\
\hline & Model 1 & Model 2 & Model 3 & Model 4 \\
\hline Germany & $\begin{array}{l}0.561 * * * \\
(0.088)\end{array}$ & $\begin{array}{l}0.380 * * * \\
(0.094)\end{array}$ & $\begin{array}{l}0.459 \text { *** } \\
(0.076)\end{array}$ & $\begin{array}{l}0.370 * * * \\
(0.081)\end{array}$ \\
\hline Denmak & $\begin{array}{l}0.313 * * * \\
(0.077)\end{array}$ & $\begin{array}{l}0.196 * \\
(0.085)\end{array}$ & $\begin{array}{l}0.337 * * * \\
(0.067)\end{array}$ & $\begin{array}{l}0.150 * \\
(0.074)\end{array}$ \\
\hline Norway & $\begin{array}{l}0.425 * * * \\
(0.087)\end{array}$ & $\begin{array}{l}0.192 * \\
(0.096)\end{array}$ & $\begin{array}{l}0.623 \text { *** } \\
(0.082)\end{array}$ & $\begin{array}{l}0.497 * * * \\
(0.086)\end{array}$ \\
\hline UK & $\begin{array}{l}0.292 * * * \\
(0.081)\end{array}$ & $\begin{array}{l}0.271 * * \\
(0.091)\end{array}$ & $\begin{array}{l}0.081 \\
(0.067)\end{array}$ & $\begin{array}{l}0.078 \\
(0.074)\end{array}$ \\
\hline Italy \& Spain & $\begin{array}{l}-0.226 * * * \\
(0.065)\end{array}$ & $\begin{array}{l}-0.123+ \\
(0.074)\end{array}$ & $\begin{array}{l}-0.660 * * * \\
(0.057)\end{array}$ & $\begin{array}{l}-0.489 * * * \\
(0.064)\end{array}$ \\
\hline Level of education: primary or less & & Ref. & & Ref. \\
\hline Lower secondary & & $\begin{array}{l}0.427 * * * \\
(0.082)\end{array}$ & & $\begin{array}{l}0.473 * * * \\
(0.074)\end{array}$ \\
\hline Upper secondary and post-secondary, non-tertiary & & $\begin{array}{l}0.571 * * * \\
(0.080)\end{array}$ & & $\begin{array}{l}0.933 * * * \\
(0.073)\end{array}$ \\
\hline Tertiary-professional degree & & $\begin{array}{l}0.816 * * * \\
(0.106)\end{array}$ & & $\begin{array}{l}1.413 * * * \\
(0.089)\end{array}$ \\
\hline Tertiary_-bachelor's, master's, research degree & & $\begin{array}{l}1.014 * * * \\
(0.097)\end{array}$ & & $\begin{array}{l}1.451 * * * \\
(0.085)\end{array}$ \\
\hline Numeracy skills & & $\begin{array}{l}0.006 * * * \\
(0.0005)\end{array}$ & & $\begin{array}{l}0.004 * * * \\
(0.0005)\end{array}$ \\
\hline Readiness to learn & & $\begin{array}{l}0.073 * * \\
(0.024)\end{array}$ & & $\begin{array}{l}0.097 * * * \\
(0.022)\end{array}$ \\
\hline Host language usage & & $\begin{array}{l}-0.115 \\
(0.110)\end{array}$ & & $\begin{array}{l}0.285 * * \\
(0.090)\end{array}$ \\
\hline Years since migration & & $\begin{array}{l}0.011 * \\
(0.005)\end{array}$ & & $\begin{array}{l}0.020 * * * \\
(0.004)\end{array}$ \\
\hline Age & & $\begin{array}{l}-0.070 * * * \\
(0.003)\end{array}$ & & $\begin{array}{l}-0.038 * * * \\
(0.002)\end{array}$ \\
\hline Living with a spouse or partner & & $\begin{array}{l}0.727 * * * \\
(0.051)\end{array}$ & & $\begin{array}{l}0.117 * * \\
(0.043)\end{array}$ \\
\hline Having children & & $\begin{array}{l}0.490 * * * \\
(0.056)\end{array}$ & & $\begin{array}{l}-0.029 \\
(0.051)\end{array}$ \\
\hline Constant & $\begin{array}{l}1.180 * * * \\
(0.050)\end{array}$ & $\begin{array}{l}1.454 * * * \\
(0.220)\end{array}$ & $\begin{array}{l}0.746 * * * \\
(0.044)\end{array}$ & $\begin{array}{l}-0.071 \\
(0.185)\end{array}$ \\
\hline Observations & 20,943 & 20,943 & 22,937 & 22,937 \\
\hline
\end{tabular}

Robust standard errors in parentheses; $+p<0.10, * p<0.05, * * p<0.01$, *** $p<0.001$.

We aggregated Belgium \& the Netherlands as well as Italy \& Spain due to small numbers of observations for these countries (see Table 7) 
Table 6 Linear regression models on the occupational status, regression coefficients from gender-specific models with single countries

\begin{tabular}{|c|c|c|c|c|}
\hline \multirow[t]{2}{*}{ DV: occupational status (ISEI) } & \multicolumn{2}{|l|}{ Men } & \multicolumn{2}{|l|}{ Women } \\
\hline & Model 1 & Model 2 & Model 3 & Model 4 \\
\hline Immigrant (effect for France) & $\begin{array}{l}-7.677 * * * \\
(1.346)\end{array}$ & $\begin{array}{l}-6.400 * * * \\
(1.584)\end{array}$ & $\begin{array}{l}-9.339 * * * \\
(1.702)\end{array}$ & $\begin{array}{l}-8.280 * * * \\
(1.689)\end{array}$ \\
\hline \multicolumn{5}{|l|}{ Interaction effects } \\
\hline Immigrant $\times$ Belgium \& Netherlands & $\begin{array}{l}0.559 \\
(2.083)\end{array}$ & $\begin{array}{l}0.541 \\
(1.624)\end{array}$ & $\begin{array}{l}2.542 \\
(2.428)\end{array}$ & $\begin{array}{l}1.360 \\
(1.774)\end{array}$ \\
\hline Immigrant $\times$ Germany & $\begin{array}{l}-1.947 \\
(2.137)\end{array}$ & $\begin{array}{l}-0.300 \\
(1.540)\end{array}$ & $\begin{array}{l}1.271 \\
(2.525)\end{array}$ & $\begin{array}{l}0.584 \\
(1.959)\end{array}$ \\
\hline Immigrant $\times$ Denmark & $\begin{array}{l}4.073 * \\
(1.982)\end{array}$ & $\begin{array}{l}0.082 \\
(1.568)\end{array}$ & $\begin{array}{l}-0.968 \\
(2.197)\end{array}$ & $\begin{array}{l}-2.864+ \\
(1.704)\end{array}$ \\
\hline Immigrant $\times$ Norway & $\begin{array}{l}0.376 \\
(2.206)\end{array}$ & $\begin{array}{l}0.183 \\
(1.781)\end{array}$ & $\begin{array}{l}1.030 \\
(2.522)\end{array}$ & $\begin{array}{l}1.033 \\
(1.884)\end{array}$ \\
\hline Immigrant $\times \mathrm{UK}$ & $\begin{array}{l}3.602 \\
(2.399)\end{array}$ & $\begin{array}{l}-0.986 \\
(1.943)\end{array}$ & $\begin{array}{l}5.318 * \\
(2.414)\end{array}$ & $\begin{array}{l}-1.861 \\
(1.916)\end{array}$ \\
\hline Immigrant $\times$ Italy \& Spain & $\begin{array}{l}-0.795 \\
(1.933)\end{array}$ & $\begin{array}{l}0.344 \\
(1.696)\end{array}$ & $\begin{array}{l}-5.712 * * \\
(2.191)\end{array}$ & $\begin{array}{l}-2.916 \\
(1.771)\end{array}$ \\
\hline \multicolumn{5}{|l|}{ Country (effect for natives) } \\
\hline Belgium \& Netherlands & $\begin{array}{l}7.110 * * * \\
(0.623)\end{array}$ & $\begin{array}{l}3.503 * * * \\
(0.503)\end{array}$ & $\begin{array}{l}5.561 * * * \\
(0.649)\end{array}$ & $\begin{array}{l}4.881 * * * \\
(0.507)\end{array}$ \\
\hline Germany & $\begin{array}{l}2.592 * * \\
(0.751)\end{array}$ & $\begin{array}{l}-1.420 * \\
(0.564)\end{array}$ & $\begin{array}{l}1.474+ \\
(0.762)\end{array}$ & $\begin{array}{l}1.529 * * \\
(0.568)\end{array}$ \\
\hline Denmak & $\begin{array}{l}4.324 * * * \\
(0.734)\end{array}$ & $\begin{array}{l}0.836 \\
(0.593)\end{array}$ & $\begin{array}{l}9.207 * * * \\
(0.750)\end{array}$ & $\begin{array}{l}5.722 * * * \\
(0.601)\end{array}$ \\
\hline Norway & $\begin{array}{l}6.346 * * * \\
(0.754)\end{array}$ & $\begin{array}{l}1.155+ \\
(0.598)\end{array}$ & $\begin{array}{l}5.564 * * * * \\
(0.779)\end{array}$ & $\begin{array}{l}0.823 \\
(0.579)\end{array}$ \\
\hline UK & $\begin{array}{l}2.726 * * \\
(0.802)\end{array}$ & $\begin{array}{l}0.128 \\
(0.639)\end{array}$ & $\begin{array}{l}1.359+ \\
(0.765)\end{array}$ & $\begin{array}{l}1.136+ \\
(0.613)\end{array}$ \\
\hline Italy \& Spain & $\begin{array}{l}-2.040 * * \\
(0.645)\end{array}$ & $\begin{array}{l}0.280 \\
(0.511)\end{array}$ & $\begin{array}{l}0.058 \\
(0.718)\end{array}$ & $\begin{array}{l}1.895 * * * \\
(0.524)\end{array}$ \\
\hline Level of education: Primary or less & & Ref. & & Ref. \\
\hline Lower secondary & & $\begin{array}{l}1.799 * * \\
(0.629)\end{array}$ & & $\begin{array}{l}3.222 * * * \\
(0.672)\end{array}$ \\
\hline Upper secondary and post-secondary, non-tertiary & & $\begin{array}{l}6.060 * * * \\
(0.624)\end{array}$ & & $\begin{array}{l}9.908 * * * \\
(0.661)\end{array}$ \\
\hline Tertiary_professional degree & & $\begin{array}{l}16.760 * * * \\
(0.791)\end{array}$ & & $\begin{array}{l}22.356 * * * \\
(0.767)\end{array}$ \\
\hline Tertiary_-bachelor's, master's, research degree & & $\begin{array}{l}28.983 * * * \\
(0.721)\end{array}$ & & $\begin{array}{l}31.777 * * * \\
(0.740)\end{array}$ \\
\hline Numeracy skills & & $\begin{array}{l}0.082 * * * \\
(0.004)\end{array}$ & & $\begin{array}{l}0.074 * * * \\
(0.004)\end{array}$ \\
\hline Readiness to learn & & $\begin{array}{l}2.254 * * * \\
(0.169)\end{array}$ & & $\begin{array}{l}1.970 * * * \\
(0.177)\end{array}$ \\
\hline Host language usage & & $\begin{array}{l}0.952 \\
(0.712)\end{array}$ & & $\begin{array}{l}1.356+ \\
(0.788)\end{array}$ \\
\hline Years since migration & & $0.185 * * *$ & & $0.226 * * *$ \\
\hline
\end{tabular}


Table 6 (continued)

\begin{tabular}{|c|c|c|c|c|}
\hline \multirow[t]{2}{*}{ DV: occupational status (ISEI) } & \multicolumn{2}{|l|}{ Men } & \multicolumn{2}{|l|}{ Women } \\
\hline & Model 1 & Model 2 & Model 3 & Model 4 \\
\hline & & $(0.041)$ & & $(0.044)$ \\
\hline Age & & $\begin{array}{l}0.145 * * * \\
(0.015)\end{array}$ & & $\begin{array}{l}0.140 * * * \\
(0.015)\end{array}$ \\
\hline Living with a spouse or partner & & $\begin{array}{l}1.432 * * * \\
(0.379)\end{array}$ & & $\begin{array}{l}0.533 \\
(0.347)\end{array}$ \\
\hline Having children & & $\begin{array}{l}-0.603 \\
(0.382)\end{array}$ & & $\begin{array}{l}-0.919 * \\
(0.378)\end{array}$ \\
\hline Full-time work & & $\begin{array}{l}0.644 \\
(0.485)\end{array}$ & & $\begin{array}{l}3.114 * * * \\
(0.310)\end{array}$ \\
\hline Constant & $\begin{array}{l}43.407 * * * \\
(0.483)\end{array}$ & $\begin{array}{l}-3.152 * \\
(1.537)\end{array}$ & $\begin{array}{l}44.778 \text { *** } \\
(0.507)\end{array}$ & $\begin{array}{l}-4.107 * * \\
(1.533)\end{array}$ \\
\hline Observations & 16,477 & 16,477 & 15,729 & 15,729 \\
\hline Adjusted $\mathrm{R}^{2}$ & 0.037 & 0.436 & 0.044 & 0.455 \\
\hline
\end{tabular}

Robust standard errors in parentheses, $+\mathrm{p}<0.10,{ }^{*} \mathrm{p}<0.05, * * \mathrm{p}<0.01, * * * \mathrm{p}<0.001$

We aggregated Belgium \& the Netherlands as well as Italy \& Spain due to small numbers of observations for these countries (see Table 7)

Table 7 Number of observations in the receiving countries

\begin{tabular}{llllll}
\hline Number of observations & \multicolumn{2}{l}{ Men } & & \multicolumn{2}{l}{ Women } \\
\cline { 6 - 6 } \cline { 5 - 6 } & Natives & Immigrants & & Natives & Immigrants \\
\hline Country clusters: & & & & \\
Northwesten Europe & 11,943 & 1643 & & 12,174 & 1885 \\
UK & 2789 & 292 & & 3865 & 424 \\
Southern Europe & 3910 & 366 & & 4098 & 491 \\
Countries: & & & & \\
Belgium & 1807 & 123 & & 1856 & 156 \\
Denmark & 2463 & 547 & & 2450 & 684 \\
France & 2433 & 330 & & 2562 & 326 \\
Germany & 1820 & 254 & & 1870 & 289 \\
Netherlands & 1853 & 167 & & 1921 & 195 \\
Norway & 1567 & 222 & 1515 & 235 \\
UK & 2789 & 292 & 3865 & 424 \\
Italy & 1813 & 110 & 1921 & 182 \\
Spain & 2097 & 256 & 2177 & 309 \\
\hline
\end{tabular}


Table 8 Descriptive statistics

\begin{tabular}{|c|c|c|c|c|}
\hline Variables & Mean/proportion & Std. dev. & Min & Max \\
\hline \multicolumn{5}{|l|}{ Dependent variables } \\
\hline Occupational status (ISEI) & 47.41 & 21.66 & 11.01 & 88.96 \\
\hline Employment & 0.73 & - & 0 & 1 \\
\hline \multicolumn{5}{|l|}{ Independent variables } \\
\hline Immigrant & 0.12 & - & 0 & 1 \\
\hline Men & 0.48 & - & 0 & 1 \\
\hline \multicolumn{5}{|l|}{ Country cluster: } \\
\hline Northwestern Europe & 63.00 & - & 0 & 1 \\
\hline UK & 16.80 & - & 0 & 1 \\
\hline Southern Europe & 20.20 & - & 0 & 1 \\
\hline \multicolumn{5}{|l|}{ Country: } \\
\hline Belgium \& Netherlands & 18.41 & - & 0 & 1 \\
\hline Denmark & 14.00 & - & 0 & 1 \\
\hline France & 12.88 & - & 0 & 1 \\
\hline Germany & 9.65 & - & 0 & 1 \\
\hline Norway & 8.07 & - & 0 & 1 \\
\hline UK & 16.80 & - & 0 & 1 \\
\hline Italy \& Spain & 20.20 & - & 0 & 1 \\
\hline \multicolumn{5}{|l|}{ Level of education (ISCED): } \\
\hline Primary or less & 8.47 & - & 0 & 1 \\
\hline Lower secondary & 17.09 & - & 0 & 1 \\
\hline Upper secondary and post-secondary, non-tertiary & 37.56 & - & 0 & 1 \\
\hline Tertiary—professional degree & 11.93 & - & 0 & 1 \\
\hline Tertiary—bachelor's, master's, research degree & 24.94 & - & 0 & 1 \\
\hline Numeracy skills & 266.77 & 54.65 & 26.73 & 452.43 \\
\hline Readiness to learn & 2.04 & 0.94 & -1.07 & 4.64 \\
\hline Host language usage & 0.93 & - & 0 & 1 \\
\hline Years since migration & 2.08 & 7.37 & 0 & 64 \\
\hline Age & 45.52 & 11.41 & 25 & 65 \\
\hline Living with a spouse or partner & 0.71 & - & 0 & 1 \\
\hline Having children & 0.75 & - & 0 & 1 \\
\hline Full-time work & 0.73 & - & 0 & 1 \\
\hline
\end{tabular}

Unweighted statistics

Numeracy skills are reported on a 500-point scale; readiness to learn is a standardized index based on six items 
Table 9 Differences in immigrants' employment disadvantages across countries, average marginal effects from gender-specific logistic regression models

\begin{tabular}{|c|c|c|c|c|}
\hline \multirow{2}{*}{$\begin{array}{l}\text { Differences in employment probabilities } \\
\text { between immigrants and natives as } \\
\text { compared with Northwestern Europe }\end{array}$} & \multicolumn{2}{|l|}{ Men } & \multicolumn{2}{|l|}{ Women } \\
\hline & Model 1 & Model 2 & Model 3 & Model 4 \\
\hline UK & $\begin{array}{l}0.068 * \\
(0.031)\end{array}$ & $\begin{array}{r}0.031 \\
(0.034)\end{array}$ & $\begin{array}{l}0.063+ \\
(0.034)\end{array}$ & $\begin{array}{l}-0.027 \\
(0.035)\end{array}$ \\
\hline Southern Europe & $\begin{array}{l}0.037 \\
(0.031)\end{array}$ & $\begin{array}{l}-0.020 \\
(0.031)\end{array}$ & $\begin{array}{l}0.176 * * * \\
(0.031)\end{array}$ & $\begin{array}{l}0.114 * * * \\
(0.032)\end{array}$ \\
\hline
\end{tabular}

Standard errors in parentheses; $+p<0.10, * p<0.05, * * p<0.01, * * * p<0.001$

Acknowledgements Financial support from the German Research Foundation (DFG) within the priority programme 1764 “The German Labour Market in a Globalized World” is gratefully acknowledged.

Code Availability Not applicable

Author Contribution Not applicable

Funding Open Access funding enabled and organized by Projekt DEAL. This work was supported by the German Research Foundation (DFG) under grant (AB 111/9-2) and (DA 1654/1-2).

Data Availability Not applicable

\section{Declarations}

Conflict of Interest The authors declare no competing interests.

Open Access This article is licensed under a Creative Commons Attribution 4.0 International License, which permits use, sharing, adaptation, distribution and reproduction in any medium or format, as long as you give appropriate credit to the original author(s) and the source, provide a link to the Creative Commons licence, and indicate if changes were made. The images or other third party material in this article are included in the article's Creative Commons licence, unless indicated otherwise in a credit line to the material. If material is not included in the article's Creative Commons licence and your intended use is not permitted by statutory regulation or exceeds the permitted use, you will need to obtain permission directly from the copyright holder. To view a copy of this licence, visit http://creativecommons.org/licenses/by/4.0/.

\section{References}

Adsera, A., \& Chiswick, B. R. (2007). Are there gender and country of origin differences in immigrant labor market outcomes across European destinations? Journal of Population Economics, 20(3), 495-526.

Aleksynska, M., \& Tritah, A. (2013). Occupation-education mismatch of immigrant workers in Europe: Context and policies. Economics of Education Review, 36, 229-244.

Algan, Y., Dustmann, C., Glitz, A., \& Manning, A. (2010). The economic situation of first and secondgeneration immigrants in France, Germany and the United Kingdom. The Economic Journal, 120(542), F4-F30.

Ballarino, G., \& Panichella, N. (2015). The occupational integration of male migrants in Western European countries: Assimilation or persistent disadvantage? International Migration, 53(2), 338-352.

Ballarino, G., \& Panichella, N. (2018). The occupational integration of migrant women in Western European labor markets. Acta Sociologica, 61, 126-142. 
Borjas, G. J. (1987). Self-selection and the earnings of immigrants. The American Economic Review, 77(4), 531-553.

Borjas, G. J. (1994). The economics of immigration. Journal of Economic Literature, 32, 1667-1717.

Castagnone, E., Nazio, T., Bartolini, L., \& Schoumaker, B. (2015). Understanding transnational labor market trajectories of African-European migrants: Evidence from the MAFE survey. International Migration Review, 49(1), 200-231.

Chiswick, B. R. (1979). The economic Progress of immigrants: Some apparently universal patterns. In W. Fellner (Ed.), Contemporary economic problems (pp. 357-399). Washington, DC: American Enterprise Institute.

Chiswick, B. R., Lee, Y. L., \& Miller, P. W. (2005). A longitudinal analysis of immigrant occupational mobility: A test of the immigrant assimilation hypothesis. International Migration Review, 39(2), 332353.

Chiswick, B. R., \& Miller, P. W. (2007). Computer usage, destination language proficiency and the earnings of natives and immigrants. Review of Economics of the Household, 5(2), 129-157.

Chiswick, B. R., \& Miller, P. W. (2009). The international transferability of immigrants' human capital. Economics of Education Review, 28(2), 162-169.

Damelang, A., \& Abraham, M. (2016). You can take some of it with you! A vignette study on the acceptance of foreign occupational certificates and ethnic inequality on the German labor market. Zeitschrift für Soziologie, 45, 91-106.

Damelang, A., Abraham, M., Ebensperger, S., \& Stumpf, F. (2019). The hiring prospects of foreign-educated immigrants: A factorial survey among German employers. Work, Employment and Society, 33(5), 739758.

di Belgiojoso, E. B., \& Ortensi, L. E. (2019). Satisfied after all? Working trajectories and job satisfaction of foreign-born female domestic and care workers in Italy. Journal of Ethnic and Migration Studies, 45(13), 2527-2550.

Diehl, C., Lubbers, M., Mühlau, P., \& Platt, L. (2016). Starting out: New migrants' socio-cultural integration trajectories in four European destinations. Ethnicities, 16(2), 157-179.

Engelen, E. (2006). Towards an explanation of the performance differences of Turks in the Netherlands and Germany: The case for a comparative political economy of integration. Tijdschrift voor Economische en Sociale Geografie, 97(1), 69-79.

Eurostat. (2018). Migrant integration statistics. http://ec.europa.eu/eurostat/statistics-explained/index.php? title=Migrant_integration_statistics. Accessed 13 April 2018.

Fleischmann, F., \& Dronkers, J. (2010). Unemployment among immigrants in European labor markets: An analysis of origin and destination effects. Work, Employment and Society, 24(2), 337-354.

Forster, A. G., Bol, T., \& van de Werfhorst, H. G. (2016). Vocational education and employment over the life cycle. Sociological Science, 3, 473-494.

Ganzeboom, H. B. G., De Graaf, P. M., \& Treiman, D. J. (1992). A standard international socio-economic index of occupational status. Social Science Research, 21(1), 1-56.

Ganzeboom, H. B. G., \& Treiman, D. J. (2017). International Stratification and Mobility File: Conversion Tools. http://www.harryganzeboom.nl/ismf/index.htm. Accessed 21 April 2017.

Haberfeld, Y., Cohen, Y., Kalter, F., \& Kogan, I. (2011). Differences in earnings assimilation of immigrants from the former Soviet Union to Germany and Israel during 1994-2005: The interplay between context of reception, observed, and unobserved immigrants' attributes. International Journal of Comparative Sociology, 52(1-2), 6-24.

Hanushek, E. H., Schwerdt, G., Wiederhold, S., \& Woessmann, L. (2015). Returns to skills around the world: Evidence from PIAAC. European Economic Review, 73, 103-130.

Ichou, M. (2014). Who they were there: Immigrants' educational selectivity and their children's educational attainment. European Sociological Review, 30(6), 750-765.

Kanas, A., \& van Tubergen, F. (2009). The impact of origin and host country schooling on the economic performance of immigrants. Social Forces, 88(2), 893-916.

Kogan, I. (2006). Labor markets and economic incorporation among recent immigrants in Europe. Social Forces, 85(2), 697-721.

Koopmans, R. (2010). Trade-offs between equality and difference: Immigrant integration, multiculturalism and the welfare state in cross-National Perspective. Journal of Ethnic and Migration Studies, 36(1), 1-26.

Lancee, B. (2016). The negative side effects of vocational education: A cross-National Analysis of the relative unemployment risk of young non-Western immigrants in Europe. American Behavioral Scientist, 60(56), 659-679.

Lancee, L., \& Bol, T. (2017). The transferability of skills and degrees: Why the place of education affects immigrant earnings. Social Forces, 96(2), 691-716. 
Li, P. (2001). The market worth of immigrants' educational credentials. Canadian Public Policy/Analyse de Politiques, 27(1), 23-38.

MacKenzie, R., \& Forde, C. (2009). The rhetoric of the 'good worker' versus the realities of employers use and the experience of migrant workers. Work, Employment and Society, 23(1), 142-159.

Mood, C. (2010). Logistic regression: Why we cannot do what we think we can do, and what we can do about it. European Sociological Review, 26(1), 67-82.

OECD. (2015). In it together: Why less inequality benefits all. Paris: OECD Publishing.

OECD. (2016a). Society at a Glance 2016: OECD social indicators. Paris: OECD Publishing.

OECD. (2016b). Skills matter: Further results from the survey of adult skills. In OECD Skills Studies. Paris: OECD Publishing.

OECD. (2016c). Technical Report of the Survey of Adult Skills (PIAAC) (second edition).

OECD. (2017). International migration outlook 2017. Paris: OECD Publishing.

Pichler, F. (2011). Success on European labor markets: A cross-national comparison of attainment between immigrant and majority populations. International Migration Review, 45(4), 938-978.

Polavieja, J. G., Fernández-Reino, M., \& Ramos, M. (2018). Are migrants selected on motivational orientations? Selectivity patterns amongst international migrants in Europe. European Sociological Review, 34(5), 570-588.

Portes, A., \& Rumbaut, R. G. (2001). Legacies: The story of the immigrant second generation. University of California Press.

Portes, A., \& Rumbaut, R. G. (2006). Immigrant America: A portrait (3rd ed.). University of California Press.

Prokic-Breuer, T., \& McManus, P. A. (2016). Immigrant educational mismatch in Western Europe, apparent or real? European Sociological Review, 32(3), 411-438.

Reitz, J. G. (2002). Host societies and the reception of immigrants: Research themes, emerging theories and methodological issues. International Migration Review, 36(4), 1005-1019.

Reyneri, E., \& Fullin, G. (2011). Labor market penalties of new immigrants in new and old receiving west European countries. International Migration, 49(1), 31-57.

Smith, T. W. (1995). Some aspects of measuring education. Social Science Research, 24(3), 215-242.

United Nations. (2017). International migration report 2017: Highlights. United Nations.

United Nations. (2020). World economic situation and prospects. United Nations.

van Tubergen, F., Maas, I., \& Flap, H. (2004). The economic incorporation of immigrants in 18 Western societies: Origin, destination, and community effects. American Sociological Review, 69(5), 704-727.

Wiley, N. F. (1967). The ethnic mobility trap and stratification theory. Social Problems, 15(2), 147-159.

Zeng, Z., \& Xie, Y. (2004). Asian-Americans' earnings disadvantage reexamined: The role of place of education. American Journal of Sociology, 109(5), 1075-1108.

Zorlu, A. (2016). Immigrants' occupational mobility - Down and back up again. IZA World of Labor, 290. https://doi.org/10.15185/izawol.290.

Publisher's Note Springer Nature remains neutral with regard to jurisdictional claims in published maps and institutional affiliations. 